\title{
Fuel Poverty Challenges in Serbia: Evidence from the Suburban Settlement of Kaluđerica
}

\author{
Tanja Bajić \\ Institute of Architecture and Urban \& Spatial Planning of \\ Serbia, IAUS \\ Belgrade, Serbia \\ tanja@iaus.ac.rs
}

\begin{abstract}
Nowadays, fuel poverty is a globally recognized social and energy problem which is significantly influenced by low household incomes and high energy prices, as well as the built form elements. Although official data indicate that the average household in Serbia is a fuel poor household, namely that it spends more than $10 \%$ of its monthly income on energy services, this issue is not sufficiently addressed in national policies and academic research. This paper indicates the vulnerability to fuel poverty of people living in illegally built suburban areas in Serbia. The results of the survey conducted in the settlement of Kaluderica on the outskirts of Belgrade show a low level of energy efficiency and high car fuel consumption as key factors affecting the pronounced burden of fuel spending within family budgets. Due to inefficient heating systems and inadequate energy performances of buildings, many households are forced to use risky methods of energy saving that can have harmful effects on their health, and also erode their quality of life.
\end{abstract} Serbia

Keywords - fuel poverty, suburban settlement, Kaluđerica,

\section{INTRODUCTION}

Fuel poverty is recognized as a serious social and energy problem that is gaining importance with rising electricity prices and awareness of the negative effects of climate change.

The concept of fuel poverty has been discussed in various studies over the last three decades. According to its first definition by Isherwood and Hancock from 1979, it refers to the phenomenon in which households spend more than twice the median (i.e. 12\%) on fuel, light and power [1]. Twelve years later, in her book entitled "Fuel Poverty", Brenda Boardman gave a new interpretation and quantification of the concept, according to which fuel poor households are those that "are unable to obtain an adequate level of energy services, particularly warmth, for 10 percent of their income" [2]. This definition and the indicator of $10 \%$ as a percentage threshold of income that "needs to be spent" for obtaining an adequate level of wintertime warmth $\left(21^{\circ} \mathrm{C}\right.$ in the living room and $18^{\circ} \mathrm{C}$ in the other occupied rooms) was adopted as the official definition of fuel poverty in the UK Fuel Poverty Strategy 2001 [3], to be later also accepted as a conceptual model in other countries. The possibility of obtaining heating was a key element of the first considerations of the phenomenon, primarily because of concerns about the negative effects of cold homes on health, and especially because of the problem of excess winter deaths (EWD) that is more pronounced in the United Kingdom than in other northern countries with similar climates. Amongst the

\author{
Jasna Petrić \\ Institute of Architecture and Urban \& Spatial Planning of \\ Serbia, IAUS \\ Belgrade, Serbia \\ jasna@iaus.ac.rs
}

consequences of fuel poverty, the most frequent include: restricted use of heating, cold and damp homes, debts on utility bills and a reduction in household expenditure on other essential items. In addition, fuel poverty is associated with a wide range of physical and mental illnesses, such as depression, asthma and heart diseases, etc. [4]

Although the factors contributing to the incidence of fuel poverty are complex, the most pronounced causes include: 1) low household incomes; 2) high electricity prices; and 3) poor energy performance of housing stock. The energy used in homes is directly dependent on social stratification, namely on economic possibilities, as well as on the individual preferences and habits of tenants [5], while the factors of built form, like location and energy-relevant characteristics of residential buildings, have an important role. Although wealthier households consume more energy on average, their homes are more often newer and more energy efficient, while poor people's homes have greater energy losses because of their low quality and inefficient heating systems. Pronounced fuel poverty is especially linked to rural areas due to the absence of district heating systems, poor energy performances of residential buildings and a significant share of low-income elderly households, as well as the problem of high fuel costs for cars.

The operational definitions of fuel poverty that explain the structure of fuel poverty and enable its measurement and monitoring differ from context to context, thus making it difficult to compare the severity of this problem between different countries. The percentage share of the population that cannot afford adequate heating and the percentage share of the population in energy arrears are most frequently used as indicators for this phenomenon, but other indicators for the energy performance of residential buildings are also used. There are also differences in defining expenditure on energy, so that the concept of fuel poverty in the British context primarily refers to domestic energy consumption, while, for example in France, the notion of "energy precarity" is increasingly applied to both the home and transport in relation to energy use.

There is a significant increase in concern about the problem of fuel poverty with East European countries joining the European Union. According to statistical data on the incomes and living conditions of EU households (EU SILC 2011), 9.9\% of households are unable to keep their home adequately warm in a great number of countries of Western, Central and 
HASSACC

Northern Europe, while in other parts of Europe this percentage ranges from 10 to 19, apart from Portugal and Latvia (20$29.9 \%$ ) and Bulgaria and Lithuania (over 30\%) [6]. The same source shows that there is almost an equal share of households in arrears on utility bills, a problem which is most pronounced in Greece, Romania, Bulgaria, Slovenia, Croatia and Latvia $(20-29.9 \%)$ [7].

The post-socialist countries of South-eastern Europe are particularly vulnerable to fuel poverty. They are characterized by a low level of energy efficiency, as well as high share of expenditure on energy in the housing sector. In this region, the economic and political changes in the early 1990s contributed to an abrupt increase in energy prices and a reduction in household incomes, as well as to a number of problems in the production and supply of energy due to technical damage and the inadequate maintenance of already outdated infrastructure and technology. At the same time, the massive privatization of social apartments has raised a complex issue of the management, maintenance and possibility of improving the energy efficiency of this inherited energy-inefficient housing stock

Cross-regional comparison shows that the efficiency of the Serbian energy system is one of the lowest, and energy intensity is amongst the highest (the ratio of energy consumed to real GDP), which is a result of energy intensive industries, energy-inefficient technologies used in households, industry and energy sectors, and poorly-insulated buildings [8]. Data from the 2013 Survey on Income and Living Conditions conducted according to the EU SILC methodology show that in Serbia $18.3 \%$ of the respondents live in households unable to keep their home adequately warm, and as many as approximately $37 \%$ of households have arrears on their utility bills, which is more than the EU average [9]. Extensive illegal residential construction widespread all over the country, especially on the periphery of large cities - Belgrade and Novi Sad [10], is a specific phenomenon directly linked to the problem of fuel poverty. Such illegal construction is characterized by locations in suburban and peripheral areas of cities, the absence of district heating systems, single-family detached houses as a dominating typology, and lower construction standards. It is estimated that in Serbia there are from 600,000 to 1 million of such houses (out of a total of 2.95 million units) [11]. This paper will consider the challenges of fuel poverty in Serbia using the example of Kaluđerica, a suburban settlement of Belgrade, which is considered the largest completely built illegal settlement in the Balkans, and most probably in Europe [12].

\section{FUEL POVERTY IN SERBIA}

Although widespread in Serbia, the fuel poverty problem is not yet an important topic in national policies and academic research. Like in other countries in the region, this issue is mainly addressed through tariff subsidies and social policy mechanisms, and not sufficiently through energy efficiency improvements. In Serbia, energy efficiency is primarily considered as a means for increasing energy security, and it is focused on the domain of energy generation [e.g. 13] and industry, rather than on households vulnerable to fuel poverty [8]. The lack of political and research attention has also resulted in the lack of an appropriate definition of the concept of fuel poverty which would enable the measurement and monitoring of the problem and the development of an approach to solving it within the local framework. A possible starting point for considering this phenomenon in Serbia is to take into account the generally accepted fuel poverty indicator expressed as a percentage share of the monthly household income used for home energy needs. According to the broader definition of this concept used here, energy consumption is the use of fuel both in the home and for transport.

According to the 2013 Household Budget Survey (HBS), households in Serbia spend a monthly average of $11.3 \%$ of their total disposable income on household energy expenditure ${ }^{1}$ [14]. This indicates that an average Serbian household is a fuel poor household according to the Western European definition of fuel poverty with the indicator of $10 \%$. When we add the current transport expenditure ${ }^{2}$ to the household expenditure on energy, this share makes up approximately $16.7 \%$. The HBS results show that the degree of vulnerability of the population to fuel poverty is different between urban and other areas, as well as across different regions in Serbia. The share of the total household income spent on home energy bills and transport in urban areas makes up approximately $16 \%$, while in other areas it is almost $18 \%$. This difference clearly indicates the greater vulnerability to fuel poverty of rural and suburban populations that is caused by the location factor, and it primarily refers to transportation costs. According to the household income levels and total household expenditure on energy, the Belgrade region leads, particularly with regard to expenditure on electricity, central heating and public transport. The highest share of the total disposable income spent on houshold energy is recorded in Vojvodina (approximately 13\%), where the highest expenditure is on natural gas and coal. On the other hand, the percentage share of the total energy and transport expenditure in households is highest in the Sumadija and Western Serbia Region and makes up as much as $19 \%$. Fuel consumption for cars is also the highest in these areas [14].

The key fuel poverty factors in Serbia are the following: 1) high prices of fuel and district heating in relation to household income; 2) undeveloped and inefficient heating systems and a lack of alternative energy sources, making it impossible for households to save energy; and 3) a low level of energy efficiency of housing stock.

Although the price of electricity in Serbia is among the lowest in Europe [15], heating with electricity, after the heating with liquid fuel, is the least economical, except for the use of electric thermal storage heaters that use electricity supplied at a cheaper night-time rate. The use of cheaper firewood is still the least expensive type of heating, while the gas prices in Serbia are still too high and are permanently rising.

1 The household energy expenditure means the total expenditure on electricity, natural gas, bottled gas, liquid fuels, firewood, coal, central heating and hot water and other heating-related costs.

${ }^{2}$ The current transport expenditure includes the expenditure on fuels and lubricants, as well as on urban and intercity passenger transportation, including taxis. 
The 2011 Census data show that $22 \%$ of apartments in Serbia have central heating, $20.6 \%$ of them have apartmentcontained central heating, while a total of $57.2 \%$ of apartments have no installations for central heating or apartment-contained central heating [16]. According to the HBS data, over 56\% of households in Serbia use only solid fuels (wood and coal) for heating, while the share of solid fuels at the level of the poorest households makes up 86.5\% [14].

For the first time ever, the Law on Planning and Construction from 2009 introduced the concept of energy efficiency into the national regulations in the energy and construction field, as well as obligatory energy certification of buildings. One of the first steps in the process of implementing the Law and accompanying regulations in the field of energy efficiency of buildings was the energy efficiency classification of buildings in Serbia which was carried out in the period from 2011 to 2013 according to the methodology developed within the European project TABULA ${ }^{3}$. The purpose of forming the typology of buildings, published in the Atlas of Family Housing and the Atlas of Multifamily Housing [17, 18], was to assess the quality of residential buildings in Serbia regarding their energy performance. The results of this research indicate an inadequate energy efficiency status of the existing housing stock in Serbia, out of which $87 \%$ is mainly single-family detached houses. On average, approximately $83 \%$ of the listed single-family houses do not have thermal insulation, while in most of the houses that have thermal insulation, the average thickness of the thermal insulation layer (approximately $5 \mathrm{~cm}$ ) does not meet the energy efficiency standards. The inadequate thermal characteristics of windows were also recorded ( $70 \%$ of them are older than 30 years), as well as a high percentage of unfinished facades (a huge 38\% in the period 1991-2011). In the category of multi-family houses, the large heat losses are caused by non-insulated or inadequately insulated building envelopes and worn-out windows, mainly made of wood (72\%). Approximately a quarter of multi-storey buildings were built during the intense period of housing construction (19711980) that was characterized by the use of precast concrete, the thermal protection of which does not meet the current requirements and standards.

The households in Serbia faced with fuel poverty have developed different coping strategies that often have unwanted effects on their health and quality of life. According to the UNDP research carried out in 2004 [11], there are different risky saving methods and risk-free saving methods. Risky saving methods include using cheap and low-quality fuels, reducing the use of certain appliances, reducing the number of heated rooms and using fuels, such as unseasoned wood, that produce indoor pollution. Risk-free saving methods include turning off lights; switching more electricity consumption to the night, when tariffs are lower; insulating doors, windows and exterior walls; and purchasing appliances with low energy consumption. This research shows that the risky saving methods are mostly used by poor households that are not connected to the district heating systems. On the other hand, the wealthier households in Serbia in principle have no energysaving habits because they link this practice to poverty, but

${ }^{3}$ IEE project: TABULA - Typology Approach for Building Stock Energy Assessment, www.building-typology.eu when they do save energy, they use the less risky saving methods.

\section{VULNERABILITY TO FUEL POVERTY IN SUBURBAN AREAS: A CASE STUDY OF KALUĐERICA}

The illegal construction in suburban areas of the cities in Serbia, with typical examples being Belgrade and Novi Sad [10], began at the end of the 1960s primarily as a consequence of poor housing conditions and inadequate housing policies that did not provide the opportunity to all citizens to use a socially owned apartment, but neither did it provide the possibility to legally build a house with one's own money [19]. This practice was in full swing particularly in the 1990s simultaneously with the abandonment of the social housing system and with a massive inflow of refugees from the war affected areas of the former Yugoslavia. Building houses without getting the required permits, without designs and with their own hands, for many families was an easier way to provide a roof over their heads.

In addition to them being located in the urban peripheries and having different infrastructure deficiencies, the general characteristics of illegally built settlements, the so called "wild settlements", include them being made up of single-family housing (detached houses), lower building standards and a low level of energy efficiency, as well as the absence of a district heating system. The common phenomenon is that the households live in uncompleted residential buildings for a long period of time. The housing conditions, combined with the marked presence of lower income social categories, indicate a high degree of vulnerability to fuel poverty for those living in these areas. The fact that the permits required for investment and energy efficient improvements cannot be issued to illegally built structures is recognized as a specific challenge for the future energy policy in Serbia [20].

The purpose of conducting empirical research into the problem of fuel poverty in the suburban area of Belgrade was to obtain indicators for the structure of household expenditure on energy, as well as for the level of and potential factors relating to their vulnerability to fuel poverty. The settlement of Kaluđerica in the periphery of Belgrade was selected for this research as a specific example of an illegally built settlement (Fig. 1). Its urban and demographic development started in 1967, and today, in terms of the population size (approximately 27,000 inhabitants according to the 2011 Census), it has reached the size of a smaller urban settlement. This settlement belongs to the Belgrade suburban municipality of Grocka and is about $10 \mathrm{~km}$ from the city centre. Today, there are 8,831 households and 10,866 apartments with an average size of $75 \mathrm{~m}^{2}$, which is approximately $9 \mathrm{~m}^{2}$ more than the average apartment size in the Belgrade region [16]. The results of a survey on the residential preferences of the population living in this suburban settlement conducted in 2014 showed that the main motives to settle in Kaluđerica were ownership of the property, and its size, quality and value. The survey also showed that the respondents, to a great extent, expressed their dissatisfaction with the overall housing amenities and their quality of life (due to a number of infrastructure problems, lack of facilities, poor environmental quality, etc.) [21]. 
The share of households with one person who earns a regular monthly income was the highest (30\%), followed by 2 persons $(28 \%), 3$ persons $(24 \%), 4$ persons $(10 \%)$, and 5 persons $(6 \%)$ who earn regular monthly income, while one household had no regular income.

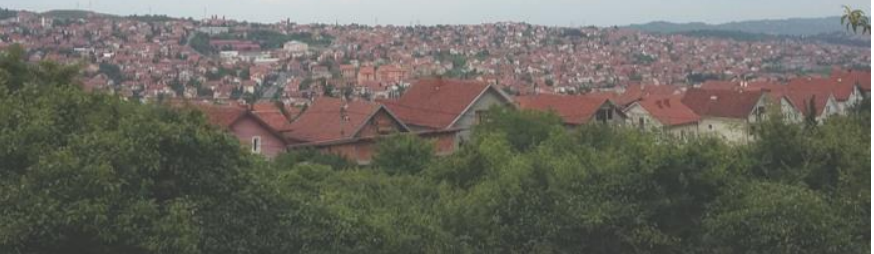

Figure 1. View on the settlement of Kaluđerica (photo: Tanja Bajić)

\section{A. Methodology}

A survey on fuel poverty in Kaluđerica was conducted in February 2015 on a representative sample of 50 households, which make up approximately $0.6 \%$ of the total number of households in the settlement according to the 2011 Census. The sample was formed by the random sampling method, taking into account only the criterion for balanced distribution of households in the settlement according to the previously designated spatial zones. The research was for the most part carried out by means of a personal in-home survey using the survey questionnaire, while a smaller share of respondents were surveyed by email. The survey was anonymous, and the answers to the survey questions were given only by one member - a representative of the household, who was a male in almost $90 \%$ of the cases and who explained his interest in participating in the survey by his better knowledge of problems relative to the female members of his household.

The questionnaire consisted of four parts. The first part of the questionnaire referred to the general data on the household, the second part referred to the household expenditure on energy, the third part referred to the energy characteristics of the family house, and the fourth part referred to the indicators for the assessment of thermal comfort. The problem of fuel poverty was considered in terms of the measurements that were carried out on the basis of the following indicators: the ratio of total household income to the household expenditures on energy (average monthly household expenditures on heating, electricity and transport); electricity bill arrears; basic energyrelevant characteristics of family houses, as well as indicators for the assessment of thermal comfort, which were all defined according to the national methodology used within the TABULA project [17].

\section{B. General Data on Housholds}

The average size of the households surveyed was 4.4 persons per household, while the size of several households surveyed was 8 persons. The four-person households are the most represented (30\%), followed by five- and six-person households $(18 \%)$; the participation of two- and three-person households is uniform (12\% each), while the percentage of the single-person households is negligible. Households made up of one or more generations of parents with at least one child under 19 years of age were the dominating household type $(58 \%)$, followed by households with children over 20 years of age $(22 \%)$, while households with two or more persons with no children were represented with $18 \%$.

\section{Expenditure on Energy}

According to the survey data, as many as $66 \%$ of the households in Kaluđerica spend over $20 \%$ of their total monthly household income on household energy and transportation costs. For the same needs, $20 \%$ of the households spend $15-20 \%$ of their total monthly household income, $10 \%$ of them spend $10-15 \%$ of their total monthly household income and only $4 \%$ of the households spend less than $10 \%$ of their disposable income (Fig. 2).

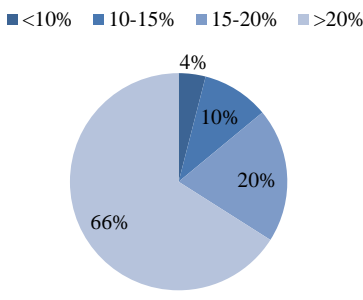

Figure 2. Share of households, grouped by average expenditure on energy services (as \% of the total monthly income)

In approximately two thirds of the households surveyed, the use of solid fuels (wood and coal) is a dominant source of household heating, where firewood is the most represented fuel, used by $66 \%$ of the households. Electricity is the second heating source represented (14\%), while the third dominant heating source is modern biomass pellet stoves (12\%), which have become an increasingly popular option (Fig. 3). Over half of the households have individual central heating or apartmentcontained central heating, while more than one third of homes are still heated with solid fuel stoves. For a smaller number of households, electric thermal storage heaters are the primary type of heating (mainly used in combination with a woodburning stove) and are most frequently used for heating the bedrooms. Approximately $40 \%$ of the households have air conditioning units that are mainly used for cooling the rooms in summer, while every fourth household also uses them for additional heating of rooms in winter.

The average monthly expenditure on electricity in the households surveyed is 5,800 RSD (cca 48 EUR) per household, which is certainly more than $12 \%$ of the average monthly net earnings in Serbia.

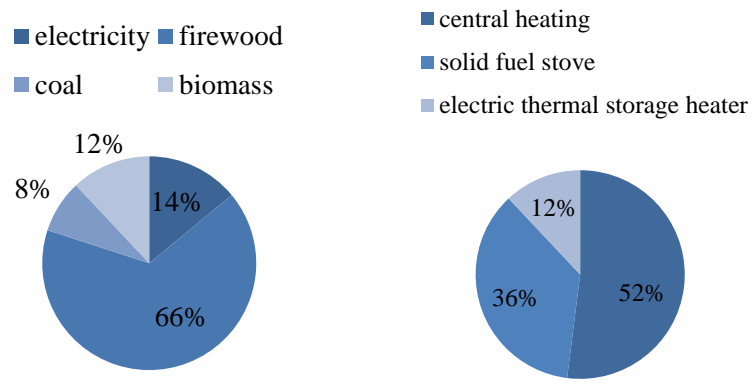

Figure 3. Household heating by primary energy sources and heating systems 
Significant expenditure on individual and public city transport is also recorded. $70 \%$ of the households use their own cars as a means of transportation and spend on average approximately 10,000 RSD (cca 83 EUR) on fuel. However, this can vary significantly and range from 1,000 RSD (cca 8 EUR) up to 50,000 RSD (cca 414 EUR). Approximately three quarters of the households spend regularly on public city transport, while there is a lower share of those that use taxis or interurban transport. According to the respondents, only $12 \%$ of the households have electricity bill arrears.

\section{Energy Characteristics of Buildings}

The analysis of the general energy characteristics of housing stock embraced by this research indicates a low level of energy efficiency, mainly due to the lack of financial resources of the residents for completing the construction of their houses. Using the random sampling method, households living in new houses built after 2000 (44\%) were mainly selected; while houses built in the 1970s, 1980s and 1990s are uniformly represented.

Approximately two thirds of the houses are detached and square-shaped, while the remaining third of them are semidetached and detached houses of elongated or non-compact shape. The share of openings on the facade of all the houses is less than $50 \%$. The majority of the houses have sloping roofs and attics that are in $28 \%$ of the cases used for dwelling, while temporary roof structures are recorded in $12 \%$ of the houses.

The exterior walls of the residential buildings are most often made of $20 \mathrm{~cm}$ thick hollow (clay) blocks, while a lower percentage of them are made of bricks, a combination of blocks and bricks, or concrete blocks. The building envelope thermal insulation is complete in $56 \%$ of the houses, while houses with partially applied thermal insulation or with no thermal insulation make up $22 \%$ (Fig. 4). $5 \mathrm{~cm}$ thick polystyrene was used as thermal insulation in most of the finished facades, while mineral wool or thinner polystyrene were used to a lesser extent. Roof heat insulation was applied in $26 \%$ of the houses, while only $40 \%$ of the houses have floor thermal insulation. Given that a significant percentage of the houses analysed were built over the last fifteen years, new double-glazed windows are the dominating type.

The windows are less than 10 years old in $52 \%$ of the cases, the windows 11-20 years old (20\%) and 21-30 (18\%) years old are relatively uniformly represented, while in $10 \%$ of the cases the windows are more than 30 years old. PVC and wood are the most common types of windows; there are fewer cases of aluminium windows, while the old wooden single glazed double-wing windows are found in the houses built in the 1970s.

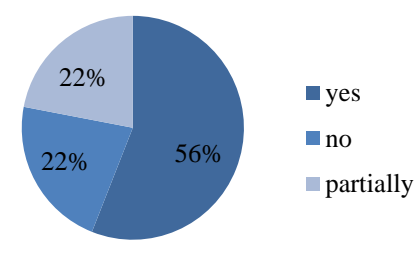

Figure 4. Thermal insulation of facades

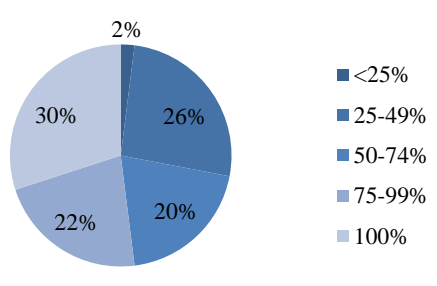

Figure 5. Share of housholds by heated area of dwelling (in \%)

\section{E. Thermal Comfort}

The family houses in Kaluđerica have two or three storeys on average, but are mostly uncompleted so that the households live in only a part of the total floor area of the house, which they heat completely or partially. In the sample analysed, the average net usable area of apartments or houses (if one household uses the entire house for living) is $135 \mathrm{~m}^{2}$. In $58 \%$ of the cases, this area is less than $100 \mathrm{~m}^{2}$, in $30 \%$ of the cases it is between 100 and $200 \mathrm{~m}^{2}$, and only in $10 \%$ of the cases is it greater than $200 \mathrm{~m}^{2}$.

Less than a third of the households surveyed heat the entire usable area in the heating season. The share of households that heat $1 / 4-1 / 2,1 / 2-3 / 4$ and over $3 / 4$ of the apartment or house is relatively uniform, while the percentage of those that heat less than 1/4 of their living space is negligible (Fig. 5). According to the subjective estimates of the respondents, approximately $50 \%$ of them were satisfied with air temperatures in their homes during the winter months, $44 \%$ of the respondents were only partially satisfied, while $6 \%$ of the respondents were not satisfied.

\section{CONCLUSIONS}

The problem of fuel poverty has not yet been sufficiently addressed in Serbia, although it affects its entire population and not only the most vulnerable social categories. This is confirmed by the data that an average household in Serbia spends more than $10 \%$ of its total monthly income on household energy costs, and almost $17 \%$ of the total monthly income on home energy bills and transport. This paper indicates the issue of fuel poverty in the context of illegally built suburban areas in Serbia using the example of the Kaluđerica settlement on the outskirts of Belgrade. Empirical research conducted using a survey questionnaire confirmed the assumption of a very pronounced vulnerability to fuel poverty among the residents of this settlement and the influence of the factor of the built form on this phenomenon.

This analysis of household expenditure on energy took into account not only the home energy expenditure, which relates to electricity and heating in the case of this settlement, but also the household transport expenditure, namely the expenses for car fuel and commuting. It was necessary to apply this wider definition of fuel poverty in the subject context in order to determine the influence of the location factor on the material deprivation of households regarding the use of energy resources. The research showed that, in addition to high energy prices in relation to disposable income, high expenses for car fuel and having an inefficient heating system (as a product of the location factor), as well as the energy inefficiency of 
residential buildings also contribute to fuel poverty in this suburban settlement. According to the data obtained, $86 \%$ of the households surveyed spend more than $15 \%$ of their monthly income on home energy bills, while for $66 \%$ of the households, this amounts to over $20 \%$ of their income, which is offered as an upper threshold for the given indicator. Many respondents in this category claimed that for them, this figure exceeded $30 \%$. For the sake of comparison, the same indicator in the region with the highest fuel poverty level recorded in Serbia is less than $20 \%$.

The survey results showed that, although the residents of Kaluđerica mostly commute by public transportation, there is a significant share of households that regularly use cars (as high as $70 \%$ ), thus spending four times more of their income than the average at the level of the city. Furthermore, commuting costs are a dominant factor in the structure of the expenditures analysed in many households. Given that Kaluđerica is not connected to the district heating system, the commonly used heating systems are: individual heating systems or apartmentcontained central heating, and the traditional solid fuel stoves, while wood and coal are used as a primary fuel in approximately two thirds of cases. Slightly more than a half of the houses embraced by the survey had a complete building envelope thermal insulation, but its thickness most frequently did not meet the current energy efficiency regulations. Nevertheless, comparing this data with the results of a survey conducted at the end of the 1980 s, when only $26 \%$ of houses in the "elite" part of Kaluđerica had finished facades [12], it may be noticed that both the availability of thermal insulation and the awareness of energy efficiency have increased. On the other hand, investments in additional energy-saving measures are still not sufficient. The extent of the influence of elementary improvements in energy efficiency on thermal comfort is shown by the data that more than a half of the respondents not satisfied with the winter temperatures in their homes lived in houses with unfinished facades. The indicators for thermal comfort also indicate that reducing the heated space is a common practice of the residents of this settlement, thus approximately $30 \%$ of the households surveyed heat less than $50 \%$ of their living area during the heating season. When we add the data on the frequent use of inefficient wood-burning stoves, as well as the use of cheap heating fuels, the problem of using risky methods of energy saving, with all of their negative effects on health and quality of life, is evident in this settlement.

This paper highlights the specifics and some of the key factors of the fuel poverty problem in Serbia which are related to the unplanned and uncontrolled development of suburban areas. Addressing this issue in further research and practice will certainly require the examination of potential ways to improve the overall energy efficiency in these areas, both in terms of housing stock and heating systems.

\section{ACKNOWLEDGMENT}

This paper is a result of the projects: "Spatial, Environmental, Energy and Social Aspects of Developing Settlements and Climate Change - Mutual Impacts", No. TR 36035 and "The Role and Implementation of the National Spatial Plan and Regional Development Documents in
Renewal of Strategic Research, Thinking and Governance in Serbia", No. III47014, which are financed by the Serbian Ministry of Education, Science and Technological Development.

\section{REFERENCES}

[1] C. Liddell, C. Morris, S. J. P. McKenzie and G. Rae, "Measuring and monitoring fuel poverty in the UK: National and regional perspectives", Energy Policy, vol. 49, pp. 27-32, 2012.

[2] B. Boardman, Fuel Poverty: From Cold Homes to Affordable Warmth. London: Belhaven Press, 1991, p. 207

[3] DEFRA, The UK Fuel Poverty Strategy 2001, Available at: http://webarchive.nationalarchives.gov.uk/20121217150421/http://decc. gov.uk/assets/decc/what\%20we\%20do/supporting\%20consumers/addres sing\%20fuel\%20poverty/strategy/file16495.pdf

[4] EU Fuel Poverty Network (2011) Working to raise awareness of fuel poverty across the $E U$. Available at: www.fuelpoverty.eu

[5] L. Lutzenhizer and B. Hackett, "Social Stratification and Environmental Degradation: Understanding Houshold CO2 Production", Social Problems, vol. 40, no. 1, pp. 50-73, 1993.

[6] C.R. Wand (2013) \% of households unable to keep their home adequately warm. Available at: http://fuelpoverty.eu.

[7] C.R. Wand (2013) \% of households in arrears on utility bills. Available at: http://fuelpoverty.eu.

[8] H. Stadtmüller (2014) "Understanding the link between energy efficiency and energy poverty in Serbia". Available at: http://rs.boell.org/sites/default/files/uploads/2014/09/stadtmueller_2014_ understandingthe_link_between_energy_efficiency_and_energy_poverty _in_serbia.pdf

[9] Statistical Office of the Republic of Serbia, Income and Living Conditions in the Republic of Serbia - 2013. Final Report. Belgrade: Statistical Office of the Republic of Serbia, 2015.

[10] J. Petrić, J. Basarić, and T. Bajić, "Urban society and resilience of Belgrade and Novi Sad in the network of settlements in Serbia - recent changes and perspectives". Proceedings of the International Conference on "Changing Cities": Spatial, morphological, formal \& socio-economic dimensions, Skiathos island, Greece, June 18 - 21, 2013. Thessaloniki: Grafima Publ., 2013, pp. 1720-1729.

[11] UNDP, Stuck in the past: Energy, environment and poverty in Serbia and Montenegro. Belgrade: UNDP, 2004.

[12] B. Saveljić, Beogradska favela, Beograd: Istraživačko-izdavački centar SSO Srbije, 1989.

[13] T. Pavlović et al., „Possibility of electricity generation using PV solar plants in Serbia“, Renewable and Sustainable Energy Reviews, vol. 20, pp. 201-218, 2013.

[14] Republički zavod za statistiku, Anketa o potrošnji domaćinstava, 2013. Beograd: Republički zavod za statistiku, 2014.

[15] EUROSTAT (2013) Energy price statistics. Available at: http://ec.europa.eu/eurostat/statisticsexplained/index.php/Energy_price_statistics

[16] Republički zavod za statistiku, Popis stanovništva, domaćinstava i stanova. Beograd: Republički zavod za statistiku, 2011.

[17] M. Jovanović Popović et al., Atlas porodičnih kuća Srbije. Beograd: Arhitektonski fakultet Univerziteta u Beogradu, 2012.

[18] M. Jovanović Popović et al., Atlas višeporodičnih zgrada Srbije. Beograd: Arhitektonski fakultet Univerziteta u Beogradu, 2013.

[19] K. Petovar, Urbana sociologija. Naši gradovi između države i građanina. Beograd: Geografski fakultet, 2003.

[20] Izveštaj sa Okruglog stola "Biomasa-održiva energija", 7.11.2014, Zlatibor (Bela zemlja). Available at: http://www.bfpe.org/wpcontent/uploads/2014/11/GIZ-biomasa_II-okrugli-sto_izvestaj.pdf

[21] J. Petrić, T. Bajić, J. Basarić, "Nekontrolisano širenje grada pod uticajem faktora rezidencijalnog izbora - primer naselja Kaluđerica u Beogradu". Monografija sa naučno-stručnog skupa "Lokalna samouprava u planiranju i uređenje prostora i naselja", Zlatibor, 3-5. april, 2014. Beograd: Asocijacija prostornih planera Srbije, 2014, str. 421-428. 